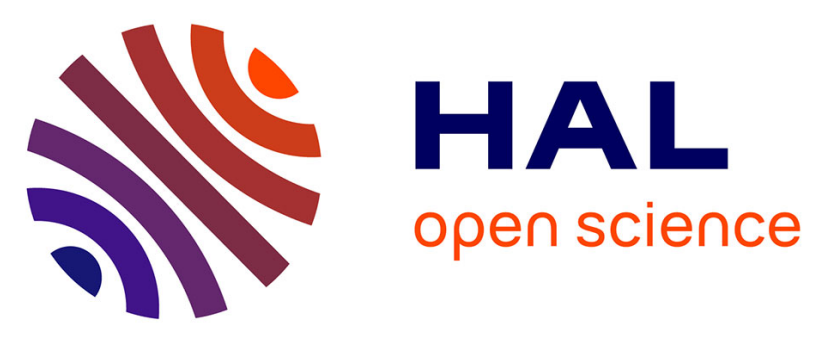

\title{
Comparisons rans and urans numerical results with experiments in a vaned diffuser of a centrifugal pump
}

Annie-Claude Bayeul-Laine, Patrick Dupont, Giovanna Cavazzini, Giorgio

Pavesi, Antoine Dazin, Patrick Cherdieu, Gérard Bois, Olivier Roussette

\section{- To cite this version:}

Annie-Claude Bayeul-Laine, Patrick Dupont, Giovanna Cavazzini, Giorgio Pavesi, Antoine Dazin, et al.. Comparisons rans and urans numerical results with experiments in a vaned diffuser of a centrifugal pump. La Houille Blanche - Revue internationale de l'eau, 2015, 2, pp.108-116. 10.1051/lhb/20150026 . hal-01170950

\section{HAL Id: hal-01170950 \\ https://hal.science/hal-01170950}

Submitted on 8 Jul 2015

HAL is a multi-disciplinary open access archive for the deposit and dissemination of scientific research documents, whether they are published or not. The documents may come from teaching and research institutions in France or abroad, or from public or private research centers.
L'archive ouverte pluridisciplinaire HAL, est destinée au dépôt et à la diffusion de documents scientifiques de niveau recherche, publiés ou non, émanant des établissements d'enseignement et de recherche français ou étrangers, des laboratoires publics ou privés. 


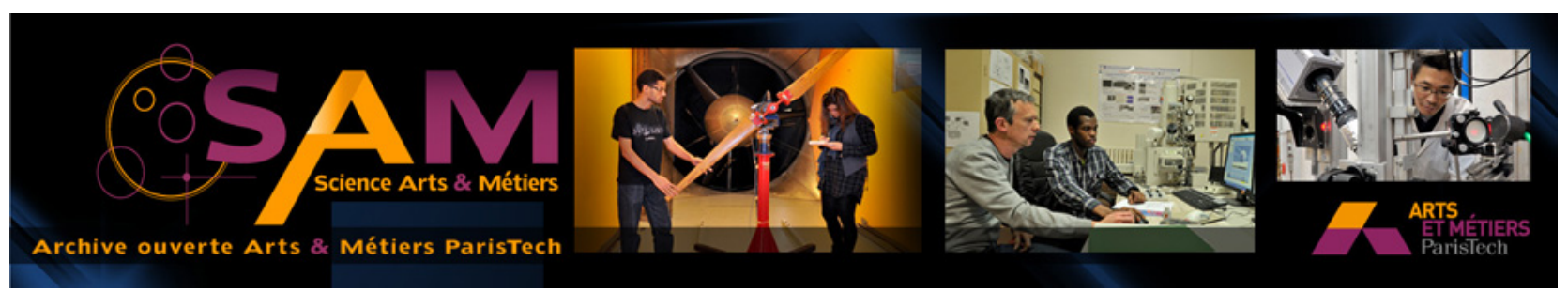

Science Arts \& Métiers (SAM)

is an open access repository that collects the work of Arts et Métiers ParisTech researchers and makes it freely available over the web where possible.

This is an author-deposited version published in: http://sam.ensam.eu

Handle ID: .http://hdl.handle.net/10985/9699

\section{To cite this version :}

Annie-Claude BAYEUL-LAINE, Patrick DUPONT, Giovanna CAVAZZINI, Giorgio PAVESI, Antoine DAZIN, Patrick CHERDIEU, Gérard BOIS, Olivier ROUSSETTE - Comparisons rans and urans numerical results with experiments in a vaned diffuser of a centrifugal pump - La Houille Blanche $n^{\circ} 2$, p.108-116 - 2015 


\title{
COMPARISONS RANS AND URANS NUMERICAL RESULTS WITH EXPERIMENTS IN A VANED DIFFUSER OF A CENTRIFUGAL PUMP
}

\author{
Annie-Claude BAYEUL-LAINÉ ${ }^{1}$, Patrick DUPONT ${ }^{2}$, Giovanna CAVAZZINI ${ }^{3}$, Giorgio PAVESI ${ }^{3}$, \\ Antoine DAZIN ${ }^{1}$, Patrick CHERDIEU ${ }^{2}$, Gérard BOIS ${ }^{1}$, Olivier ROUSSETTE ${ }^{1}$ \\ ${ }^{(1)}$ Arts et Métiers PARISTECH, LML, UMR CNRS 8107, Bd Paul Langevin, 59655 VILLENEUVE D’ASCQ-annie-claude.bayeul- \\ laine@ensam.eu \\ ${ }^{(2)}$ Ecole Centrale de Lille, LML, UMR CNRS 8107, Bd Paul Langevin, 59655 VILLENEUVE D’ASCQ \\ ${ }^{(3)}$ University of Padova, Energy and Fluids, Department of Industrial Engineering
}

\begin{abstract}
The paper presents the analysis of the performance and the internal flow behaviour in the vaned diffuser of a radial flow pump using PIV (particles image velocimetry) technique, pressure probe traverses and numerical simulations. PIV measurements have been performed at different hub to shroud planes inside one diffuser channel passage for a given rotational speed and various flow rates. For each operating condition, PIV measurements have been made for different angular positions of the impeller. Probe traverses have also been performed using a 3 holes pressure probe from hub to shroud diffuser width at different radial locations in between the two diffuser geometrical throats. The numerical simulations were realized with the two commercial codes: i-Star CCM+ 8.02.011 (RANS (Reynolds Averaged Navier Stokes) turbulence model, frozen rotor and unsteady calculations), ii-CFX 10.0 (turbulence modelled with DES model (Detached Eddy Simulation) combining RANS with LES (Large Eddy Simulation), unsteady calculations). Comparisons between numerical (fully unsteady calculations) and experimental results are presented and discussed for two flow rates. In this respect, the effects of fluid leakage due to the gap between the rotating and fixed part of the pump model are analysed and discussed.
\end{abstract}

KEYWORDS: Pump, diffuser, PIV measurements, numerical calculations, probes

\section{Comparaisons de différents modèles numériques à des résultats expérimentaux dans un diffuseur aubé de pompe centrifuge}

\begin{abstract}
L'analyse des performances et de l'écoulement interne dans un diffuseur aubé de la pompe centrifuge SHF (testée en air) fait l'objet de ce papier. La particularité de cette pompe est qu'il n'y a pas de volute à l'aval de telle sorte que l'écoulement refoule à l'air libre. Une caractéristique de ce diffuseur est que son débit nominal correspond à $80 \%$ du débit nominal de la roue. L'analyse des performances est réalisée grâce à la technique PIV (Vélocimétrie par images de particules), aux sondes de pression trois trous et aux simulations numériques. Les mesures PIV ont été réalisées pour différents plans entre le carter et le moyeu dans un canal du diffuseur, pour une vitesse de rotation de roue fixée, et différents débits. Dans chaque cas, les mesures PIV ont été effectuées pour sept différentes positions angulaires de la roue, deux positions seulement sont ici présentées. Des sondes de pression trois trous ont également été utilisées dans le diffuseur à différentes positions radiales et axiales, en entrée et sortie du diffuseur et dans le canal inter-aubes. Les simulations numériques ont été réalisées à l'aide de deux codes de calcul: i-Star CCM+ 8.02.011 (modélisations RANS en «frozen rotor» et en calculs instationnaires), ii-CFX 10.0 (calculs instationnaires, modélisation de la turbulence par DES combinant un modèle RANS avec la LES ). Les mesures réalisées avec les sondes trois trous et les résultats des simulations numériques donnent des informations sur les évolutions des coefficients de pressions statiques et dynamiques. On a pu constater que les performances globales de la machine dépendaient peu des débits de fuite. D’un point de vue local, seules les vitesses radiales et tangentielles sont ici comparées. Les courbes $\mathrm{v}_{\mathrm{r}}$ en fonction du rayon, dans le canal inter-aubes du diffuseur, pour deux débits encadrant le débit nominal de la roue, montrent que les résultats expérimentaux sont en bonne correspondance avec la courbe de simulation numérique tenant compte de fuites entre le diffuseur et la roue. L'analyse quantitative des iso valeurs $v_{\mathrm{r}}$ et $\mathrm{v}_{\mathrm{u}}$ donne une idée des structures présentes dans le diffuseur.
\end{abstract}

MOTS CLES : pompes, diffuseur, mesures PIV, modélisation, sondes

\section{INTRODUCTION}

Flow behaviour in a radial machine is quite complex and is strongly depending on rotor stator interactions and operating conditions [Adamczyk et al, 1994, Arndt et al, 1990, Eisele et al, 1997]. 
Experimental intrusive and non-intrusive standard techniques (pressure transducers, hot wire anemometers, laser techniques: Laser Doppler Velocimetry (L.D.V.) and Particle Image Velocimetry (P.I.V.)) allow the knowledge of the flow field due to rotor-stator interactions. Many experiments were conducted to measure pressure fluctuations inside the diffuser of radial pumps by Arndt et al. [1990], Furukawa et al. [2003], Guo and Maruta [2005], Pavesi et al. [2008] and the details of wake transport across the rotor were tracked in continuously running facilities thanks to laser techniques (Akin et al, 1994, Eisele et al, 1997, Akhras et al, 2004, Feng et al ,2007, Benra et al, 2008, Wuibaut et al, 2000, 2006)

In numerical simulations, two aspects have to be considered:

- the first one concerns the governing equations which are solved in the model: three kinds of numerical calculations are currently used in turbo machinery: i-frozen rotor calculations, ii-mixing plane calculations, iii-unsteady calculations. The frozen rotor is the steady state method which uses the rotating reference frame to save the computational resources by converting inherently transient turbo-machinery flow into steady state. The difference between frozen rotor and mixing plane is that mixing plane mixes the flow and applies the average quantities on the interface for upstream and downstream components, while frozen rotor will pass the true flow to downstream and vice versa. So if the wake effect on the downstream component performance is necessary, the frozen rotor method has to be used. A big disadvantage is that, it gives the solution at a single relative position. The true transient method gives the wake effect on the downstream component for all relative positions (as happens in reality) [Culver et al, 2009, Petit et al, 2013, Tamm et al, 2002]

- the second aspect concerns the geometrical model. Some geometrical simplifications are currently used. For example, the leakage flows are often neglected. It is obvious that a complex model (fully unsteady, with leakage flows) will be more time consuming but closer to the real physics.

In this paper, some limits of the numerical models are pointed out. To do so, results of several numerical calculations have been used: i-Frozen rotor without leakage (Star CCM+), ii-Unsteady RANS calculations without leakage (Star CCM+), iii- Unsteady DES (detached eddy simulation) calculations with and without leakage (CFX). These numerical results are compared to experimental results for several flow rates to try to evaluate the effects of the numerical models on the prediction of the performance and on the local behaviour of the flow.

The test model corresponds to the so-called SHF pump, working with air, in similarity conditions compared to water, for which several studies have been made [Dazin et al,2008, 2011, Cavazzini, 2006, Cavazzini et al, 2009, 2011, Wuibaut et al, 2000, 2006] involving numerical and PIV comparisons.. The existing database has been completed by pressure probe measurements in the vaned diffuser of the pump model for a more complete performance analysis.

\section{EXPERIMENTS}

\section{II.1 Test and apparatus}

\section{Table 1: Pump characteristics}

\begin{tabular}{ll|ll}
\hline Impeller & & Diffuser & \\
\hline Inlet radius & $\mathrm{R}_{1}=0.14113 \mathrm{~m}$ & Inlet radius & $\mathrm{R}_{3}=0.258 \mathrm{~m}$ \\
Outlet radius & $\mathrm{R}_{2}=0.257 \mathrm{~m}$ & Outlet radius & $\mathrm{R}_{4}=0.44 \mathrm{~m}$ \\
Number of blades & $\mathrm{Z}_{\mathrm{i}}=7$ & Number of vanes & $\mathrm{Z}_{\mathrm{d}}=8$ \\
Outlet height & $\mathrm{B}_{2}=0.0385 \mathrm{~m}$ & Height & $\mathrm{B}_{3} \mathrm{~B}_{4}=0.04 \mathrm{~m}$ \\
Impeller design flow rate & $\mathrm{Q}_{\mathrm{i}}=0.337 \mathrm{~m}^{3} / \mathrm{s}$ & Diffuser design flow rate & $\mathrm{Q}_{\mathrm{d}}=0.8 \mathrm{Q}_{\mathrm{i}}$ \\
Rotation speed & $\mathrm{N}=1710 \mathrm{rpm}$ & Impeller-Diffuser radial gap & $1 \mathrm{~mm}$ \\
\hline
\end{tabular}

Test pump model and PIV measurements conditions have been already described in several papers [Cavazzini , 2006, Cavazzini et al 2009] and main pump characteristics are given in table 1. This set-up allows the existence of a "positive" leakage flow going into the gap between impeller outlet section and inlet 
vaned diffuser section which is specific to the experimental set-up. This is due to the fact that the pump outlet corresponds to atmospheric conditions.

The PIV results come from G. Cavazzini PhD Thesis, [2006].

\section{II.2 Three holes probes}

A three holes probe has been used to make hub to shroud traverses. Using a specific calibration one can get total pressure, static pressure, absolute velocity and its two components in radial and tangential direction.

In order to well represent the flow field, twenty-three probe locations are defined as it can be seen in figure 4. For each location, ten axial positions are registered $\left(b^{*}=0.125,0.2,0.25,0.375,0.5,0.625,0.75\right.$, $0.875,0.925,0.975$ from hub to shroud). The present analysis focuses only on locations 19 to 23 in the blade to blade diffuser channel.

\section{II.3 General flow conditions}

All types of measurements have been performed for several flow rates. But, results presented in this paper refer only to two flow rates. The first one close to the design point of the vaned diffuser $Q^{*}=0.766$ which is different from the non-dimensional impeller design flow rate $\mathrm{Q}^{*}=1$ (the vaned diffuser design was chosen in order to allow an enlarge pump performance characteristic curve for low flow rates). The second normalised flow rate is equal to 1.134 .

\section{CALCULATIONS}

Frozen rotor and unsteady calculations were performed using Star CCM+ code and results are compared with already published CFX results [Cavazzini, 2006, Cavazzini et al, 2009, 2011].

\section{III.1 Frozen rotor and unsteady calculations on a simplified geometry without leakage (Star CCM+)}

The calculation domain was divided into three zones: the inlet zone, the impeller zone and the diffuser zone. The boundary condition at the inlet consisted of a flow rate. The boundary condition at the outlet was the atmospheric pressure. The fluid (air) was considered incompressible at a constant temperature of $20^{\circ} \mathrm{C}$.

A polyhedral mesh with prism layers is used for all calculations (5 prism layers for a total prism layer thickness of $1 \mathrm{~mm}$ ).

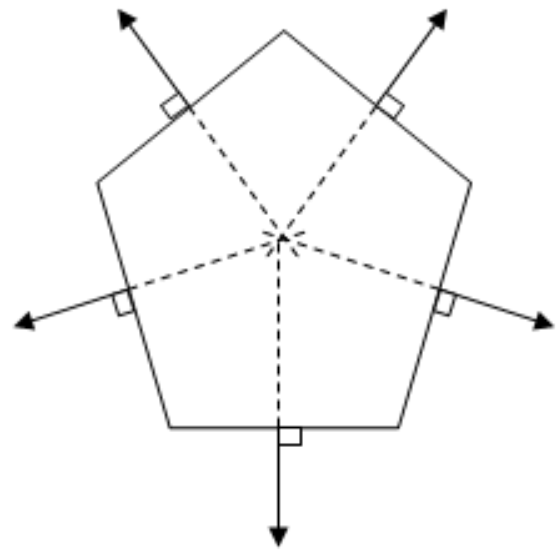

FIG. $1-\operatorname{good}$ cell

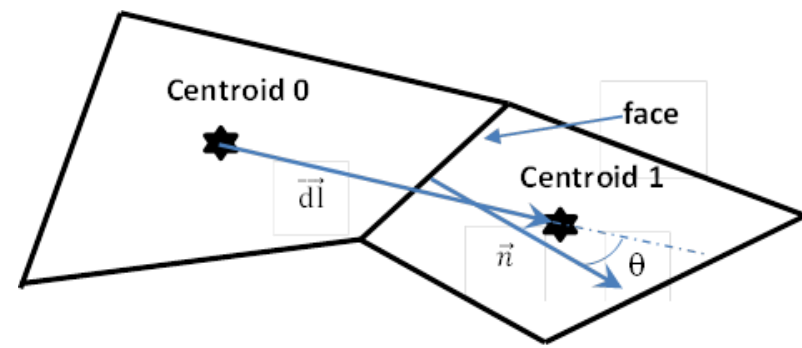

FIG. 2 - skewness angle

The quality of the mesh can be evaluated by some parameters like face validity, cell quality, skewness angle...In Star $\mathrm{CCM}+$, the volume mesh is built from the surface mesh which is always a triangular mesh. The quality of this triangular mesh is such that the face validity is equal to 1 for all cells. This means that all face normal vectors are correctly pointing away from the cell centroid, so all cells are good cells as can be seen in figure 1 . The face validity is an area-weighted measure of the correctness of the face normal vectors relative to their attached cell centroid. 
The cell quality metric algorithm is based on a hybrid of the Gauss and least-squares methods for cell gradient calculation methods. It depends on the relative geometric distribution of the cell centroids of the face neighbour cells and also on the orientation of the cell faces. In the present paper, the major part of cells has a cell quality in the range of 0.7 and 1.

The skewness angle $\theta$ is the angle between the face area vector $\mathbf{n}$ (face normal) and the vector connecting the two cell centroids, $\mathbf{d l}$ as can be seen in figure 2. All cells have a skewness angle lower than 85 degrees which is necessary in order to reduce the impact of robustness and the major part (98\%) of cells have a skewness angle in the range of 0 and 30 degrees.

The influence of the mesh size was studied in the case of frozen rotor calculations and for the nondimensional mass flow rate of $\mathrm{Q}^{*}=0.766$ by modifying the size of the base size which is a reference size. As can be observed in figure 3, the non-dimensional increase of total pressure inside the impeller and inside the pump don't change significantly for base sizes greater than $0.5 \mathrm{~m}$ which corresponds to a grid size of about 3. $10^{6}$ cells. This base size corresponds to a target size of $3 \mathrm{~mm}$ and a minimum size of $0.5 \mathrm{~mm}$.

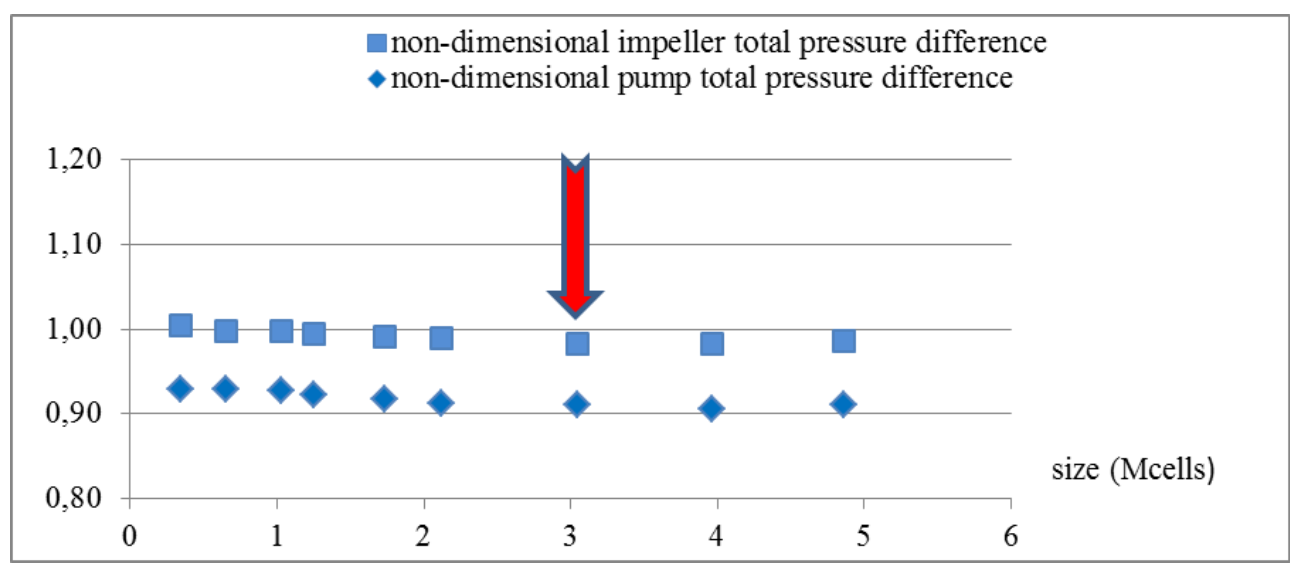

FIG. 3 - Influence of mesh size

Table 2 : Angular blade positions relative to one diffuser vane

\begin{tabular}{l|lllllll} 
& P1 & P2 & P3 & P4 & P5 & P6 & P7 \\
\hline Angular positions (deg) & 38.16 & 45.34 & 7.56 & 14.70 & 21.88 & 29.07 & 36.25
\end{tabular}

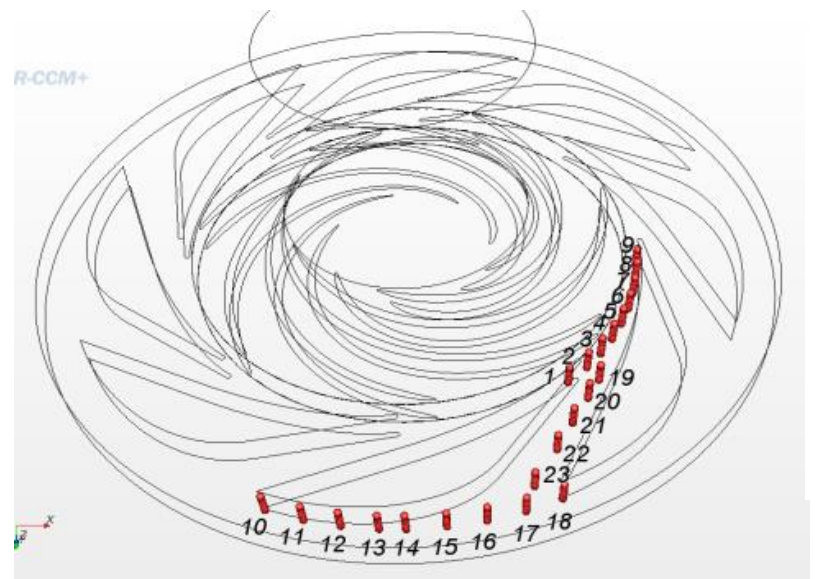

FIG. 4 - Diffuser measurement locations for probe traverse and unsteady calculations

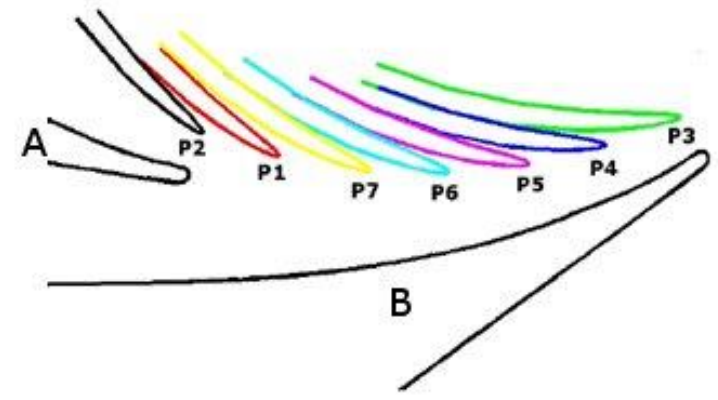

FIG.5 - Impeller different angular positions relative to the diffuser vanes

The SST k- $\omega$ turbulence model is used.

Line probes (9 locations) are plotted as defined in figure 4 in order to obtain all parameters (pressure, total pressure, radial, tangential and axial velocity and velocity magnitude) for 7 different impeller angular 
positions relative to the diffuser vanes (Figure 5, Table 2). In this paper, P3 and P7 are the only positions presented and discussed.

The convergence criteria are less than $1 . \mathrm{e}^{-4}$. Maximum values of $\mathrm{y}+$ are around 15 , and mainly below 9 in the whole computational domain. A time step, corresponding to an angular rotation of $1^{\circ}$, has been chosen.

In this part, fluid leakages are not taken account.

\section{III.2 DES calculations with and without leakages}

In order to investigate the influence of leakage flows, numerical results obtained using CFX are also presented. G. Cavazzini et al [2009, 2011] proposed two kinds of unsteady simulations, with and without leakage flows. The models and mesh were already presented in previous paper [G. Cavazzini 2009, 2011]

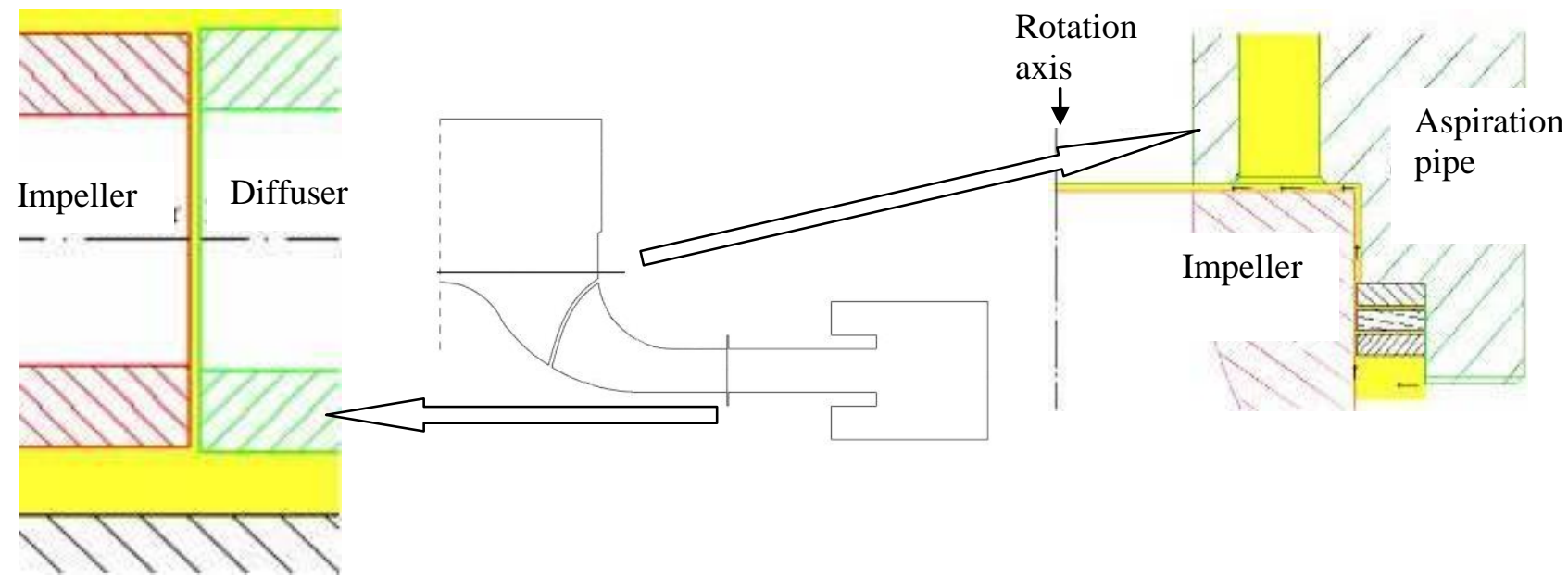

FIG.6 - Real seal system at the impeller outlet
FIG. 7 - Modelisation in CFX

\section{FIG. 8 - Real seal system at the impeller inlet}

As regards the simulations, the leakage flows inside the seal systems (figure $6 \& 8$ ) both at the impeller inlet and outlet taken into account (Figures 6-8). They were estimated by a 1D loss calculations based on the experimental pressure measurements. They were then prescribed as an inlet boundary conditions in the gap between the inlet pipe and the diffuser as well as in the one between the impeller and the diffuser (figure 7), , assuming stochastic fluctuations of the velocities with $5 \%$ free-stream turbulence intensity Much more details on model, mesh and numerical simulations are reported in ref [Cavazzini et al, 2009].

\section{RESULTS AND COMPARISONS}

\section{IV.1 Pump performances}

The numerical, experimental and theoretical performances of the pump are plotted in figure 9. All models give similar pump heads (isentropic, static, total). Furthermore, for the isentropic pump heads, the results are slightly lower than the theoretical curve which has been obtained by Euler non-dimensional approach. This means that both models predict correctly the global behaviour of the flow in the impeller.

One can note that the numerical static pressures underestimate the experimental pressure rise, whatever the numerical scheme adopted. This is particularly obvious for $\mathrm{Q} / \mathrm{Q}^{*}>1$. At these flow rates, previous studies [Cavazzini, 2006, Cavazzini et al, 2009, Wuibaut, 2000] have shown a strong boundary layer detachment at the diffuser vane leading edge. The calculations may have some difficulties to predict correctly the flow behaviour in these regions and thus overestimate the losses linked with these phenomena. One can nevertheless note that the consideration of the leakages seems to improve slightly the performance prediction.

The efficiencies are plotted figure 10. It can be noticed that the frozen rotor calculations overestimates the impeller efficiencies at partial flow rates probably because this kind of calculation is unable to predict correctly the unsteady phenomena occurring in the runner at these operating points. It can also be seen that 


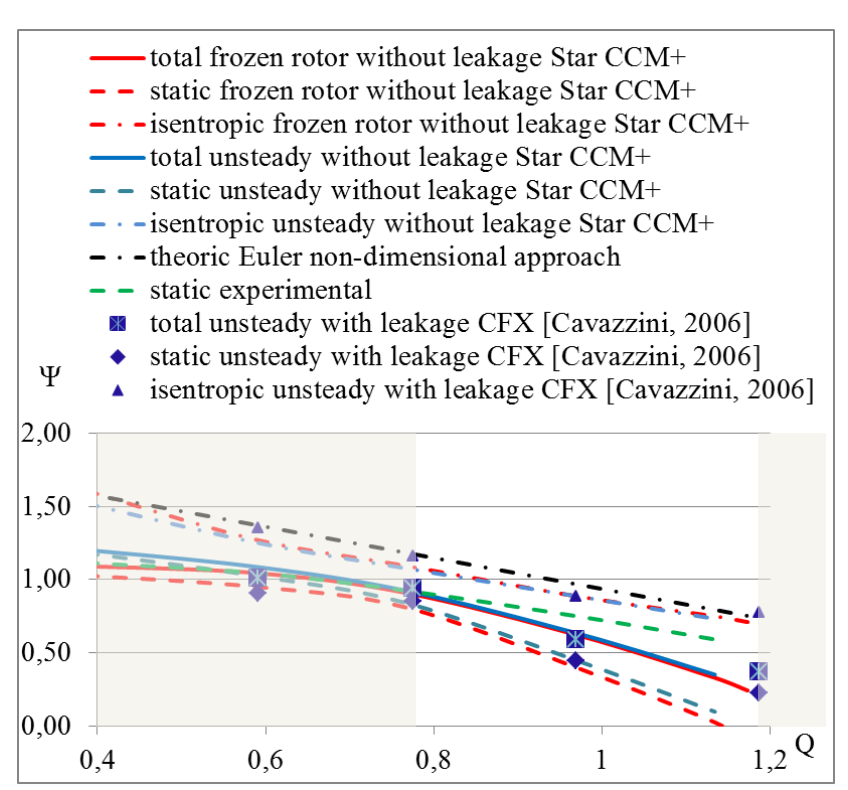

FIG.9 - Pump non-dimensional head curve reminded that the diffuser design flow rate is $\mathrm{Q}^{*}=0.766$ )

the pump efficiency falls at high flow rate. This is due to the very bad diffuser efficiency at these flow rates, because of the great desadaptation of the flow in the diffuser for this operating conditions. (It can be

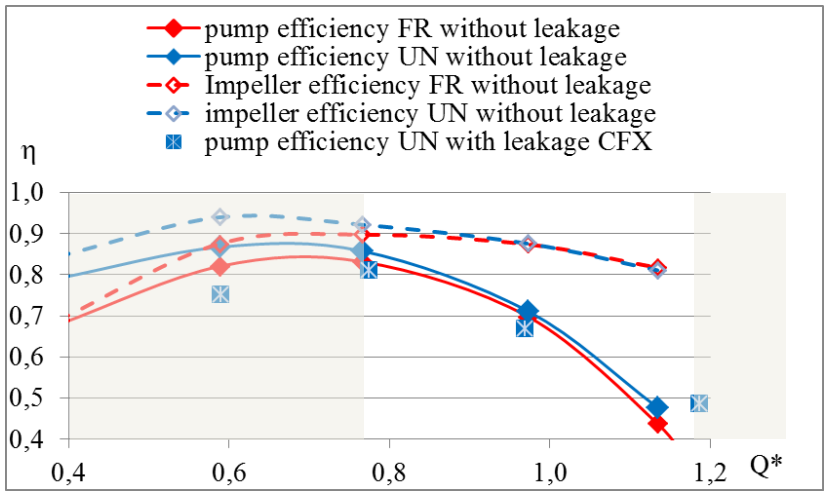

FIG.10 - Pump efficiencies

\section{IV.2 Velocity profiles}

Local results are analysed for unsteady calculations, three holes probes and PIV measurements.

Figure 11 gives the contours of radial velocities, for $\mathrm{b}^{*}=0.5$ at mid height inside the diffuser channel passage for two angular positions P3 and P7 of the impeller and for two mass flow rates : i-the diffuser design flow rate, ii- a higher mass flow rate, upper that the design mass flow rate of impeller. Figure 8 shows the contours of tangential velocities in the same conditions than figure 11. The PIV experiments are compared to unsteady Star CCM+ calculations.

The radial and tangential velocity contours at the diffuser design flow rate and for the two angular positions of the impeller are very similar for the numerical results and the PIV measurements, but with a lower magnitude of velocities in case of calculation. The examination of the contours of tangential velocity for the same flow rate and for the two angular positions leads to same comments. This tendency has also been observed for other value of $b^{*}$ by comparison between numerical calculation and between PIV done by G. Cavazzini [2006]. As the experimental results have been performed with pump configuration with leakage, it can be supposed that there is a positive leakage between impeller and diffuser.

On the contrary, it has been observed, for the radial and tangential velocities contours for high flow rate that the tendency inverses. So it can be supposed that fluid leakages are negative in this case.

Radial velocity evolutions of unsteady calculations without leakage (obtained from the two different codes: "CCM+" and "CFX 1"), and unsteady calculations with leakage (obtained only from CFX [Cavazzini et al, 2011]: "CFX 2") are presented in figures 13 and 14 for both flow rates. PIV measurements ("PIV"), and three-hole pressure probes ("probes") results are plotted on the same figures. Results present time-averaged values of radial velocities distribution from hub to shroud section as a function of radius.

The influence of leakage can be confirmed when comparing numerical results obtained without and with leakage. Experimental results are in better agreement with calculations obtained with leakage. This can be mainly observed on radial velocity distribution shown in figures 13 and 14 . For $\mathrm{Q}^{*}=0.776$, the mean relative difference between experimental and unsteady calculations radial velocities is about $30 \%$ for calculations without leakage and $13 \%$ for calculations with leakage. On the contrary for $\mathrm{Q}^{*}=1.134$ numerical results without leakage are higher than experimental ones. The mean relative difference is about $-17 \%$ for calculations without leakage and 5\% for calculations with leakage.

These results must be more deeply analysed, in particular PIV ones; they strongly depend on impeller position during its rotation and only time-averaged values are presented here. Pressure probe results are also depending on unsteady effects and this has to be taken into account for further data reduction analysis 


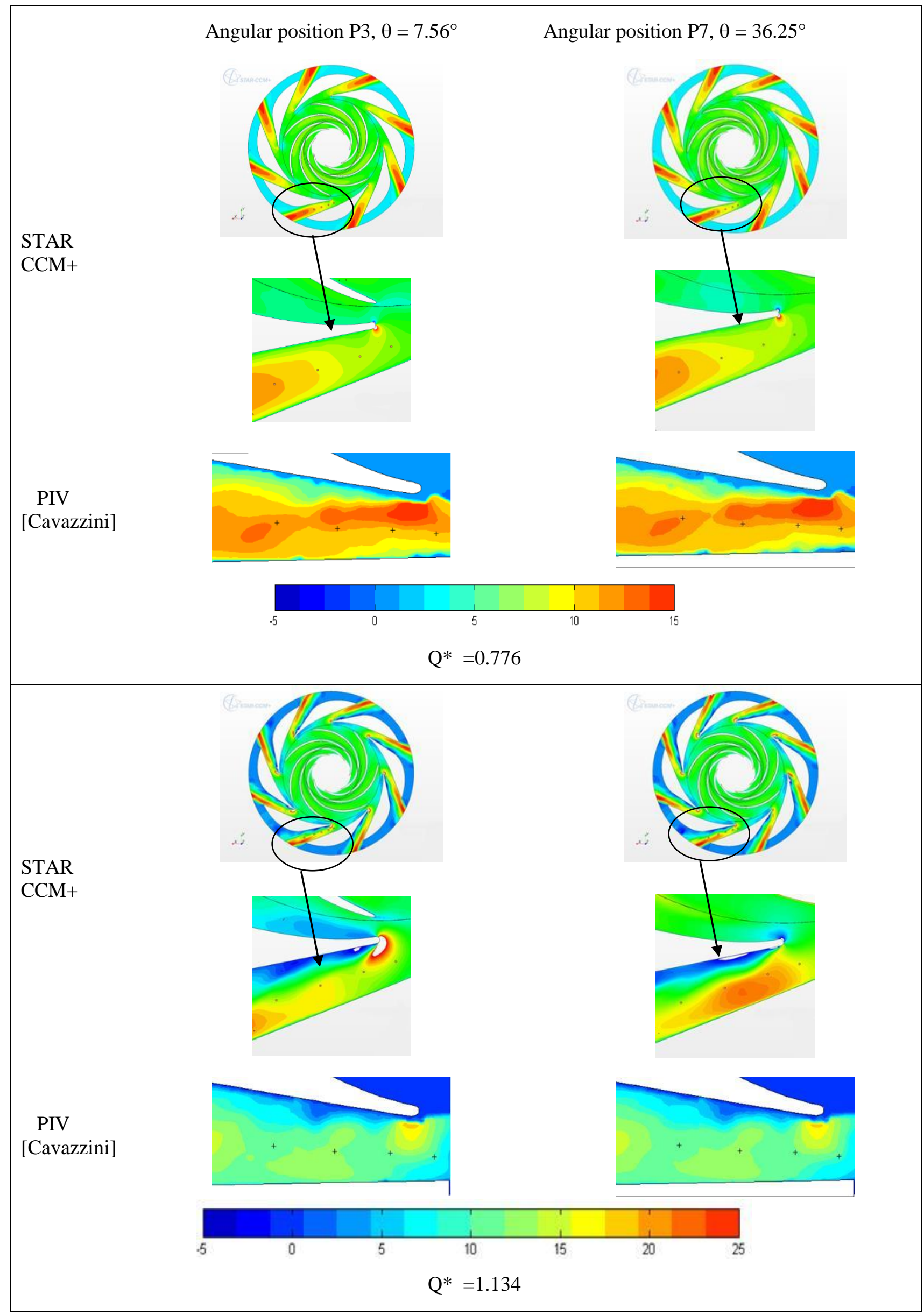




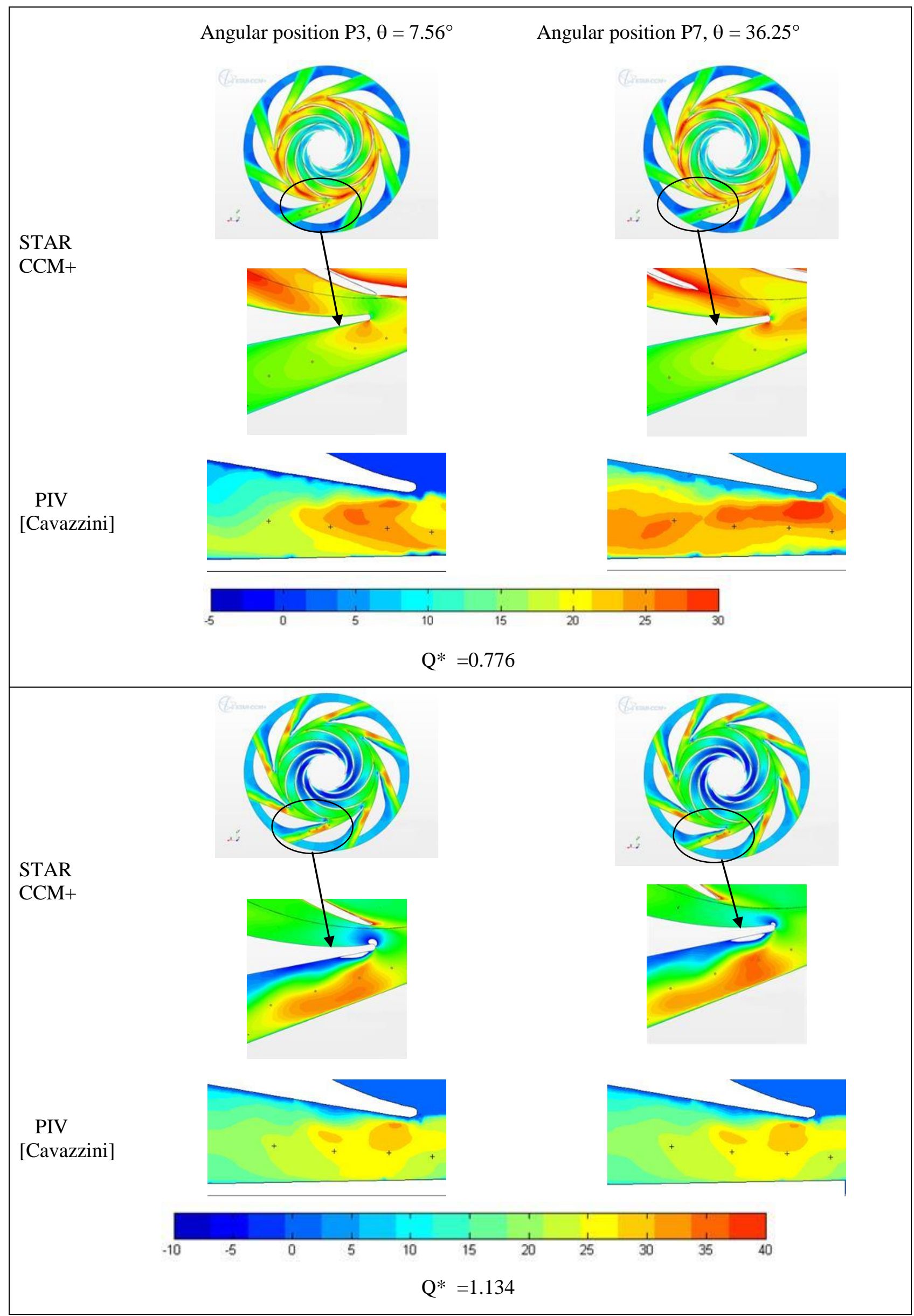




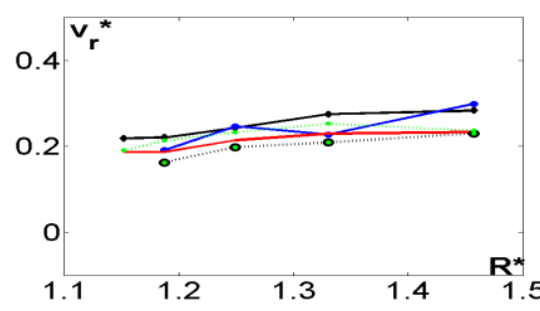

$\mathrm{b}^{*}=0,125$

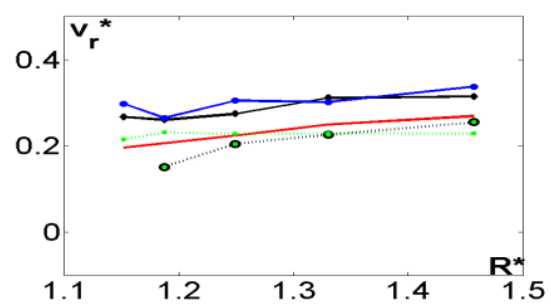

$\mathrm{b}^{*}=0,250$
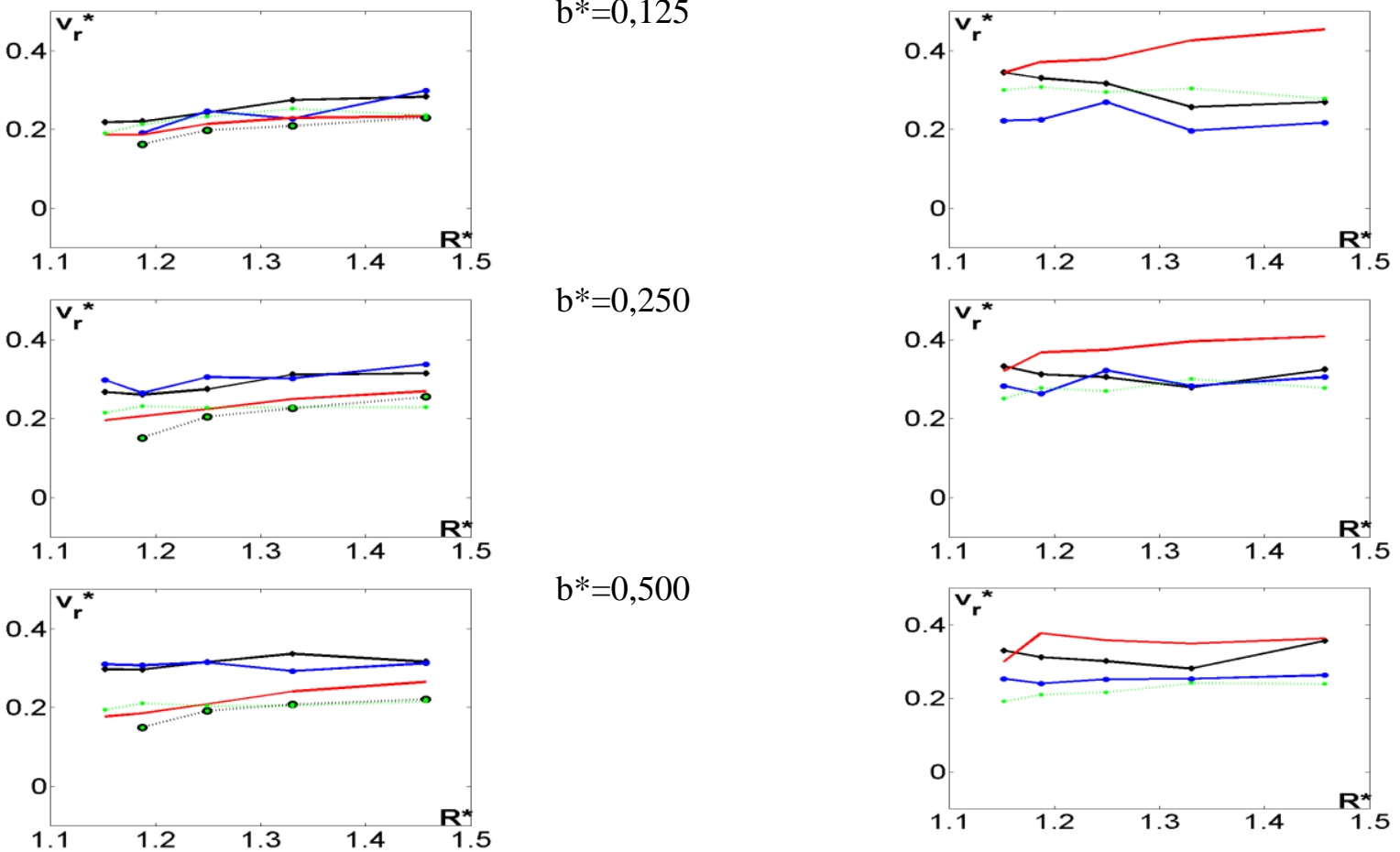

$b^{*}=0,500$
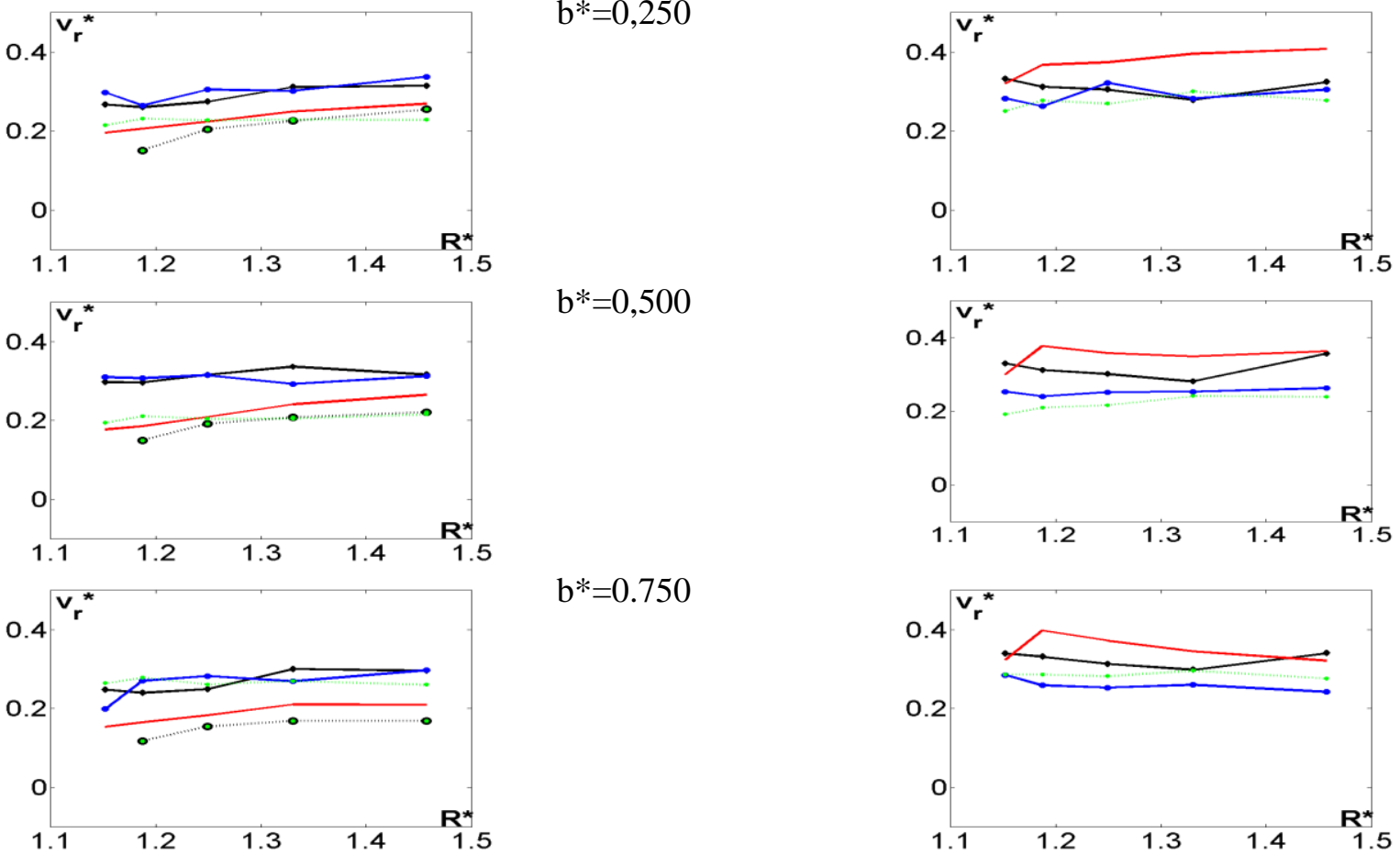

$b^{*}=0.750$
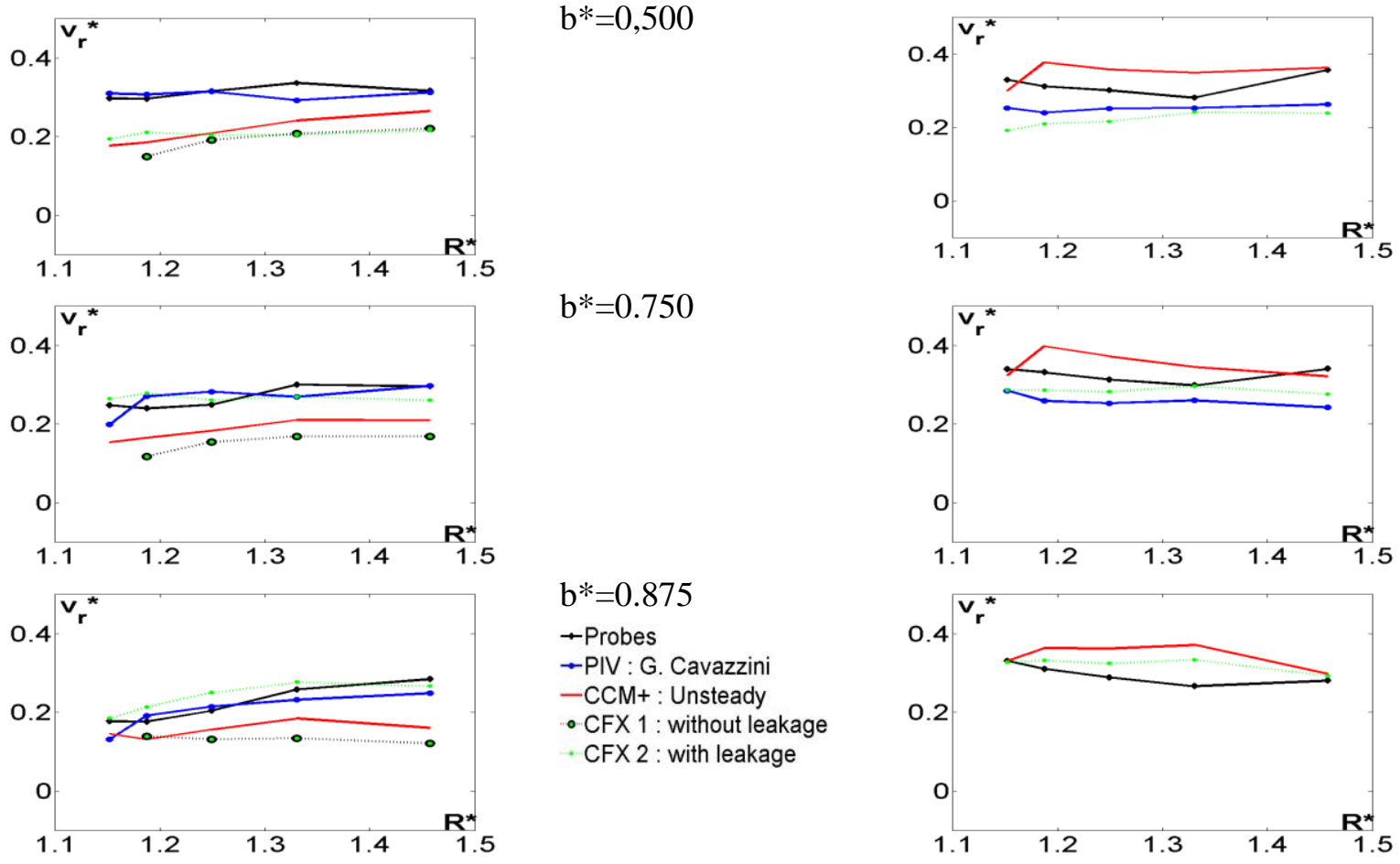

$\mathrm{b}^{*}=0.875$

$\rightarrow$ Probes

$\rightarrow$ PIV : G. Cavazzini

- CCM+ : Unsteady

- CFX 1 : without leakage

- CFX 2 : with leakage
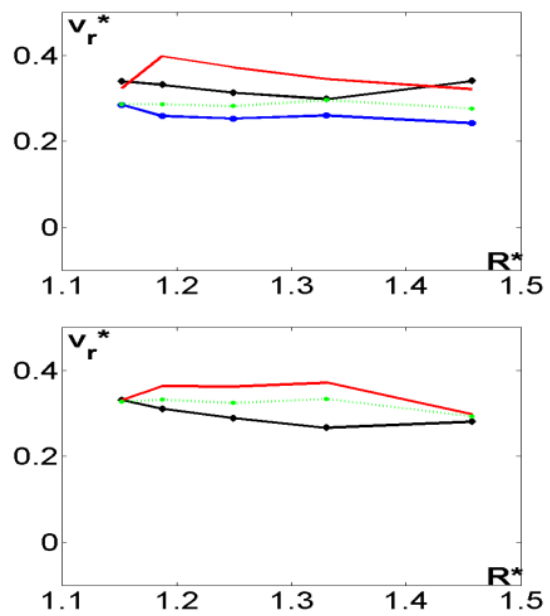

FIG. 13 - Non-dimensional radial velocity $\mathrm{Vr}^{*}$ with $\mathbf{R}^{*}$ - NumericalExperimental comparisons in horizontal cut planes $-Q^{*}=0.776$

FIG. 14 - Non-dimensional radial velocity $\mathrm{Vr}^{*}$ with $\mathrm{R}^{*}$ - NumericalExperimental comparisons in horizontal cut planes- $Q^{*}=1.134$

\section{CONCLUSIONS}

Comparisons between two numerical 3D approaches, three holes probes and PIV measurements have been presented inside the diffuser of a centrifugal impeller at different cut planes inside the diffuser. Two different impeller blade positions were considered. Two flow rates were studied. The contours of radial and tangential velocity at mid height as well as the time-averaged values of radial velocity distributions underline leakage to be an important parameter that has to be taken into account in order to make good comparisons between numerical and experiments.

Henceforth, simulations with fluid leakages will be realized and unsteady probes will be used in order to confirm these previous results. These calculations show few influence of taken account fluid leakage on global performance but a real improvement concerning velocity distributions. 
VI NOMENCLATURE

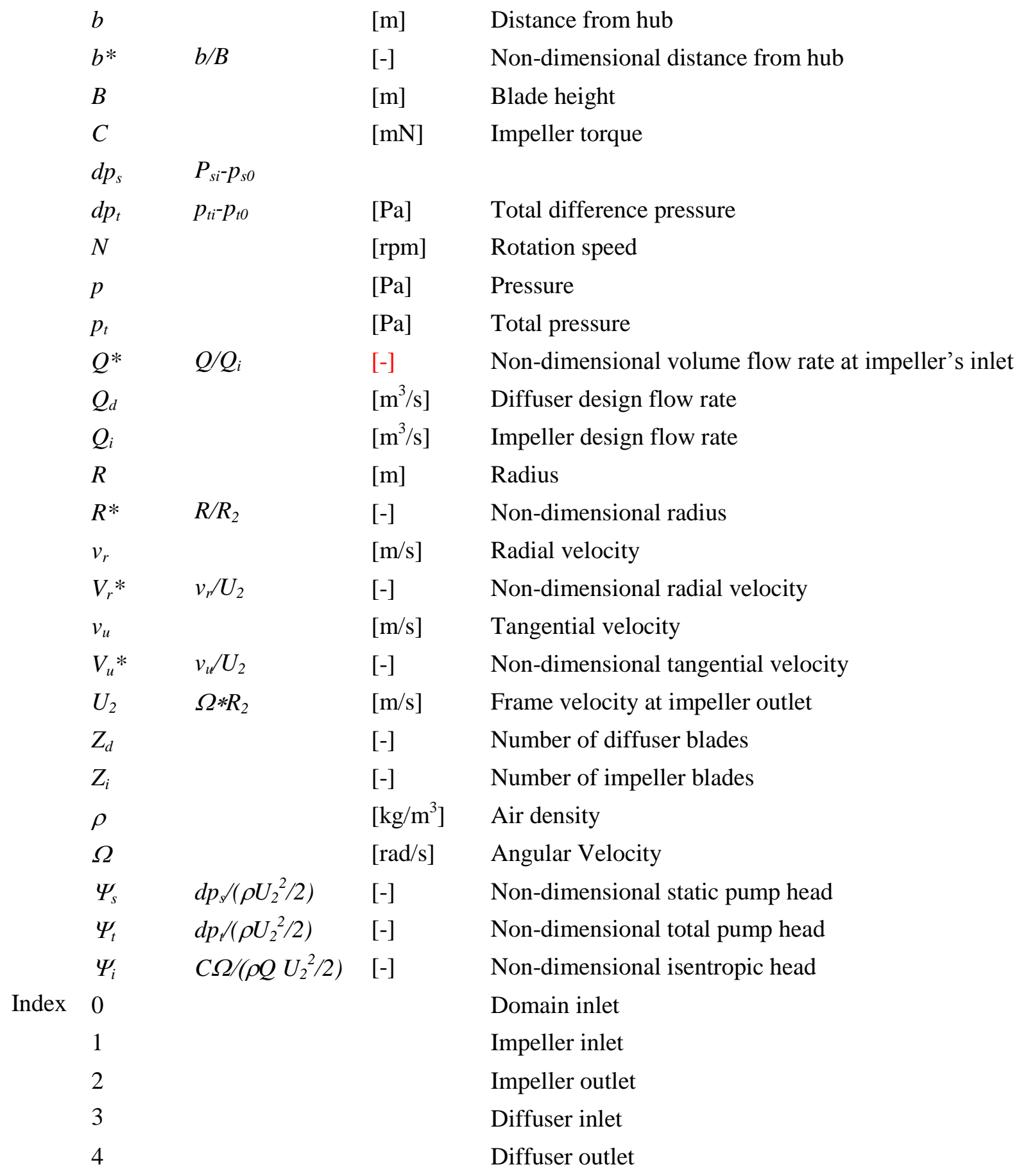

\section{REFERENCES}

Adamczyk J. J., Celestina M. L., Chen J. P. 1994, - Wake induced unsteady flows :their impact on rotor performance and wake rectification ASME International Gas Turbine and Aeroengine Congress and Exposition, The Hague, Netherlands, June 13-16, paper 94GT219.

Akin O., Rockwell D.O. 1994 -Interaction of zones of flow separation in a centrifugal impeller-stationary vane system. Exp. Fluids. 17 427-433

Akhras A., El HajemM., Champagne J.-Y., Morel R. 2004 - The flow rate influence on the interaction of a radial pump impeller and the diffuser. Int. J. Rotating Mach. 10(4) 309-317 
Arndt N., Acosta A.J., Brennen C.E., Caughey T.K 1990 - Experimental Investigation of Rotor - Stator Interaction in a Centrifugal Pump With Several Vaned Diffusers ASME Journal of Turbomachinery, Vol. 112, p. 98-108.

Benra F. K., Feng J., Dohmen J. (2008) - PIV Measurements of Unsteady Flow in a Diffuser Pump at Different Flow Rates. 12th ISROMAC, Hawaii, USA, February. 17-22

Cavazzini G 2006- Experimental and numerical investigation of the rotor-stator interaction in radial turbomachines, Ph.D. thesis, University of Padova, Padova, Italy

Cavazzini G., Pavesi G., Ardizzon G., Dupont P., Coudert S., Caignaert G., Bois G. 2009 - Analysis of the rotor-stator interaction in a radial flow pump Houille blanche - revue internationale de l'eau p. 141-151

Cavazzini G., Dupont P., Pavesi G., Dazin A., G.Bois, Atif A., Cherdieu P. 2011 - Analysis of unsteady flow velocity fields inside the impeller of a radial flow pump: PIV measurements and numerical calculation comparisons Proc. of ASME-JSME-HSME Joint fluids engineering conference July 24-29, Hamamatsu, Japan

Culver R., Liu F. 2009 - Plane Method for Flutter Computation in Multi-stage Turbomachines $47^{\text {th }}$ AIAA Aerospace Sciences Meeting Including The New Horizons Forum and Aerospace Exposition January58, Orlando, Florida

Dazin Antoine; Coutier Delgosha Olivier; Dupont Patrick; Coudert Sébastien; Caignaert Guy; Bois Gérard 2008 - Rotating Instability in the Vaneless Diffuser of a Radial Flow Pump Journal of Thermal Science 17 (4) $368-374$

Dazin Antoine; Cavazzini Giovanna; Pavesi Giorgio; Dupont Patrick; Coudert Sébastien; Ardizzon Guido; Caignaert Guy; Bois Gérard 2011 - High-speed stereoscopic PIV study of rotating instabilities in a radial vaneless diffuser Exp Fluids 51(1) 83-93

Eisele K., Zhang Z., Casey M. V., Gülich J., Schachenmann A. 1997 - Flow analysis in a Pump Diffuser Part 1: LDA and PTV Measurements of the Unsteady Flow Transactions of ASME, Journal of Fluids Engineering, Vol. 119, p. 968-977

Feng J., Benra F, Dohmen H., 2007, Numerical Investigation on Pressure Fluctuations for Different Configurations of Vaned Diffuser Pumps. International Journal of Rotating Machinery Volume 2007 (2007), Article ID 34752, 10 pages

Furukawa A., Takahara H., Nakagawa T., Ono Y. 2003 - Pressure fluctuation in a vaned diffuser downstream from a centrifugal pump impeller. Int. J. Rotating Mach. 9(4) 285-292

Guo S., MarutaY. 2005 - Experimental investigations on pressure fluctuations and vibration of the impeller in a centrifugal pump with vaned diffusers. JSME Int. J., Ser. B. 48(1) 136-143

Pavesi G., Cavazzini G., Ardizzon G. [2008] Time-frequency Characterization of the Unsteady Phenomena in a Centrifugal Pump. Int. J. Heat and Fluid Flow. 29 1527-1540

Petit O., Nilsson H. 2013 - Numerical Investigations of Unsteady Flow in a Centrifugal Pump with a vaned Diffuser International Journal of Rotating Machinery, Vol. 2013, Article ID 961580, 14 pages

Tamm A., Gugau M., Stoffel B.2002 - Experimental and 3-D Numerical Analysis of the Flow Field in Turbomachines- Part I International Congress on Quality Assesment of Numerical Simulations in Engineering, Conception - Chile

STAR CCM+ user guide

Wuibaut G., Dupont P., Caignaert G., Stanislas M. 2000 - Experimental analysis of velocities in the outlet part of a radial flow pump impeller and the vaneless diffuser using particle image velocimetry Proceedings of the XX IAHR Symposium, Charlotte (USA), 6-9 august, paper GU-03. 

of Internal Flow Investigations in SHF Impeller, Int. J. of Rotating Machinery, Vol. 2006, p. 1-9 